\title{
Bone and Soft Tissue Changes with Oral Phosphate Supplements
}

\author{
Georges H. Laflamme and Jenifer Jowsey \\ From the Mayo Clinic and Mayo Foundation, \\ Rochester, Minnesota 55901
}

A в S T RAC T Oral phosphate supplements in divided doses were given to adult dogs for a period of 10 months. Bone density, bone turnover, serum chemistry values, and the calcium content of soft tissues were determined initially and at the end of the experimental period. Serum calcium remained the same; serum phosphate decreased slightly but significantly. The decrease in phosphate was related to an increase, compared with pre-experimental values, in bone resorption which was seen in the terminal ulna and iliac crest bone samples from all dogs. Serum immunoreactive parathyroid hormone was increased (compared with pre-experimental values) after 5 and 10 months of phosphate supplementation; this increase was related to the bone loss and the decrease in serum phosphate. Soft-tissue calcification could be demonstrated histologically in the kidney and in the lens of the eye where it resulted in cataracts. Calcium content increased in the thoracic aorta, kidney, heart, and tendon but not in skeletal muscle. Phosphate supplements in adult dogs appear to produce secondary hyperparathyroidism, bone loss, and calcification of soft tissues.

\section{INTRODUCTION}

In both man and animals, oral phosphate administration has been repeatedly shown to cause a decrease in the urinary excrction of calcium (1) and a net increase in the total body retention of calcium. In vitro, in parathyroid hormone-induced resorption in tissue culture preparations, the movement of calcium from the bone is prevented by adding phosphate to the culture medium $(2,3)$. As a result, it has been suggested that phosphate supplements will cause a net increase in bone mass by either increasing bone formation or decreasing bone resorption. For this reason, phosphate supplementation has been used to treat healing fractures (4) and has been sug-

Received for publication 20 March 1972 and in revised form 24 July 1972. gested as potentially useful in the therapy of metabolic bone disease $(5,6)$. However, recent work has put in doubt the rationale behind its use in metabolic bone disease. Apart from the dangers of producing soft-tissue calcification (7), measurements of serum parathyroid hormone $(\mathrm{PTH})^{1}(8)$ and bone turnover have suggested that oral phosphate supplements may in fact result in increased bone loss $(9,10)$.

The present experiment was designed to measure directly the effects of a high daily intake of phosphate on PTH secretion and bone turnover and to discover the site of calcium retention in the body.

\section{METHODS}

Initial control studies. 10 adult female mongrel dogs were maintained for 6-18 months on a standard laboratory diet. $^{2}$ At the end of this time the dogs weighed $13.1 \pm 1.7$ $\mathrm{kg}$ (mean $\pm \mathrm{SD}$ ). They were then placed on a control diet $^{3}$ for $6 \mathrm{wk}$. Three fasting, morning blood samples (1 wk between samples) were then obtained to establish normal calcium (11), phosphate (12), alkaline phosphatase (13), magnesium (11), and blood urea nitrogen values (14). Serum immunoreactive PTH was also measured by using a single antiserum to bovine $\mathrm{PTH}$, prepared in a rooster (15). The final dilution volume was 1:7500 in an incubation volume of $0.3 \mathrm{ml}$. The immunologic cross-reactivity between canine and bovine PTH was sufficient to permit detection of circulating PTH in normal dog sera. Sera from parathyroidectomized dogs contained no assayable $\mathrm{PTH}$. All test sera gave assay curves parallel to the standard curve. The coefficient of variation of replicate samples at two widely different concentrations was $10 \%$. In addition, control 24-hr urinary calcium (10) and phosphate values (16) were obtained. All dogs were given tetracycline (15

\footnotetext{
${ }^{1}$ Abbreziation used in this paper: $\mathrm{PTH}$, parathyroid hormone.

${ }^{2}$ Tuffy's, Pine Lakes Feed Co., Perham, Minn. (0.8\% $\mathrm{P}+1.1 \% \mathrm{Ca})$.

${ }^{3}$ The diet consisted of $100 \mathrm{~g}$ of Wayne dog chow (Wayne Feeds, Allied Mills, Inc., Chicago, Ill.), $230 \mathrm{~g}$ of Red Heart canned meat (John Murrell \& Co., Chicago, Ill.), and $100 \mathrm{~g}$ of white bread; it provided $1.10 \mathrm{~g}$ of calcium and $1.05 \mathrm{~g}$ of phosphorus/dog per day.
} 
$\mathrm{mg} / \mathrm{kg}$ ) to mark new mineralizing bone surfaces. The tetracycline was given intravenously, twice at a 10 day interval. 1 month later, ${ }^{47} \mathrm{Ca}(10 \mu \mathrm{Ci} / \mathrm{kg})$ was given intravenously as a tracer for calcium, and disappearance of the isotope from blood was measured over a 5 day period $(1 \mathrm{ml}$ of heparinized whole blood was mixed with $1 \mathrm{ml}$ of water and counted in a Picker automatic $4 \pi$ counter, Picker $\mathrm{Nu}$ clear Co., White Plains, N. Y.). No difference was found between freshly mixed blood and samples in which settling had occurred. Total body retention of ${ }^{47} \mathrm{Ca}$ was determined, in anesthetized dogs lying on their stomachs, by using a single crystal approximately $2 \frac{1}{2} \mathrm{ft}$ from the dog. Measurements were made before the isotope injection, immediately after, and 3 and 4 days later.

Measurements (17) of bone mineral content were made using the Cameron-Sorenson apparatus; previous studies ${ }^{1}$ had shown that the method gives reproducible results in the area of the distal tibia. Initial control values were obtained from the left tibia at a point one-third of the total length of the bone, measuring from the distal end. The skin was shaved and tattooed to ensure a fixed point for subsequent measurements. Bone mineral content was measured three times during the control period, at weekly intervals. The measurement represented the scan area of the absorbed energy of a ${ }^{125} \mathrm{I}$ source. The width of the tibia was determined by measuring the width of the scan area at the 0.75 base line level (18). Bone biopsy specimens were taken from the midshaft of the right ulna and from the iliac crest, and cross-sections of mineralized bone were prepared for quantitative microradiography to assess bone turnover (19). The technique measures the area or surface of bone undergoing formation or resorption and is a function

'Laflamme, G. H., H. W. Wahner, and J. Jowsey. Unpublished data. of osteoblastic or osteoclastic proliferation, respectively. In addition, the holes in the cortex were counted in three cross-sections from the ulna and expressed as the average number of holes per section. Large holes were divided into unit "holes" approximately $1 \mathrm{~mm}^{2}$ on the photograph to correct for differences in hole size.

Experimental period; control dogs. Three dogs remained on the control diet for 6 months, and body weight was determined each month. Serum calcium (11), phosphate (12), and magnesium (11) and 24 hour urinary calcium (10) and phosphate were measured at intervals; serum immunoreactive parathyroid hormone (15) was measured at the end of the 6 months. Ulna and iliac crest bone biopsy specimens were taken again at the end of the study, from the corresponding site on the side opposite that sampled in the control period; sections were cut and prepared for quantitative microradiography. Soft-tissue samples from the heart, kidney, thoracic and abdominal aorta, gluteus muscle, and hamstring tendon were taken for estimation of calcium content. In addition, seven dogs which had been maintained on the standard laboratory diet were killed and similar soft-tissue samples were taken for estimation of the calcium content.

Experimental dogs. 10 adult female dogs were used. At the end of the control period, phosphate was added to the control diet (10 tablets of Hyper-Phos-K [The Kendall Co., Needham Heights, Mass.] to give a total daily intake of approximately $2.8 \mathrm{~g}$ of phosphorus/dog). This supplementation was maintained for 4 months and then increased to 12 tablets/day for a further 6 months (a daily intake of $3.1 \mathrm{~g}$ ). No complications developed except for sporadic diarrhea during the first few days of phosphate supplementation.

Measurements were made of serum calcium (11), magnesium (11), and phosphate (12) at monthly intervals for

TABLE I

Serum and Urine Values in Control and Phosphate-Treated Dogs*

\begin{tabular}{|c|c|c|c|c|c|c|}
\hline \multicolumn{4}{|c|}{ Treated dogs $(N=10)$, serum } & \multicolumn{3}{|c|}{ Control dogs $(N=3)$, serum } \\
\hline & $\mathrm{Ca}$ & $P$ & $\mathrm{Mg}$ & & $\mathrm{Ca}$ & $\mathrm{P}$ \\
\hline$w k$ & $m g / 100 \mathrm{ml}$ & $m g / 100 m l$ & $m g / 100 m l$ & $w k$ & $m g / 100 m l$ & $\mathrm{mg} / 100 \mathrm{ml}$ \\
\hline 0 & $10.3 \pm 0.4$ & $4.6 \pm 1.0$ & $1.9 \pm 0.1$ & 0 & $10.5 \pm 0.4$ & $3.9 \pm 0.1$ \\
\hline 12 & $10.7 \pm 0.4_{+}^{+}$ & $4.3 \pm 0.7 \S$ & $1.9 \pm 0.2$ & 4 & $10.1 \pm 0.6$ & $3.8 \pm 0.3$ \\
\hline 16 & $10.2 \pm 0.5$ & $3.5 \pm 0.6 \S$ & $1.9 \pm 0.1$ & 8 & $10.6 \pm 1.0$ & $4.1 \pm 0.3$ \\
\hline 20 & $10.3 \pm 0.4$ & $3.4 \pm 0.6 \S$ & $1.9 \pm 0.1$ & 12 & $9.6 \pm 1.1$ & $5.0 \pm 0.1$ \\
\hline 24 & $10.3 \pm 0.3$ & $3.9 \pm 1.3$ & $1.7 \pm 0.1$ & 28 & $10.2 \pm 0.6$ & $3.9 \pm 0.2$ \\
\hline 28 & $10.3 \pm 0.4$ & $3.6 \pm 0.7 \S$ & $1.9 \pm 0.1$ & 38 & $10.0 \pm 0.6$ & $3.9 \pm 0.1$ \\
\hline 32 & $10.2 \pm 0.5$ & $3.5 \pm 0.8 \S$ & - & & & \\
\hline 38 & $10.2 \pm 0.5$ & $3.6 \pm 0.6 \S$ & - & & & \\
\hline \multicolumn{4}{|c|}{ Treated dogs $(N=10)$, urine } & \multicolumn{3}{|c|}{ Control dogs $(N=3)$, urine } \\
\hline & $\mathrm{Ca}$ & $P$ & & & $\mathrm{Ca}$ & $\mathrm{P}$ \\
\hline$w k$ & $m g / 24 h r$ & $m g / 24 h r$ & & $w k$ & $m g / 24 h r$ & $m g / 24 h r$ \\
\hline 0 & $7.0 \pm 5.4$ & $562 \pm 250$ & & 0 & $3.3 \pm 0.1$ & $439 \pm 65$ \\
\hline 16 & $3.0 \pm 2.4$ & $1,190 \pm 750 \S$ & & 4 & $7.0 \pm 5.4$ & $584 \pm 33$ \\
\hline 32 & $2.0 \pm 0.7_{\ddagger}^{+}$ & $1,720 \pm 680 \S$ & & 28 & $5.2 \pm 0.3$ & $374 \pm 11$ \\
\hline
\end{tabular}

* Values are mean \pm SD.

$\ddagger$ For difference from value at $0 \mathrm{wk}, P<0.05$.

$\S$ For difference from value at $0 \mathrm{wk}, P<0.01$. 
TABLE II

${ }^{47} \mathrm{Ca}$ Blood Levels and Total Body Retention*

\begin{tabular}{|c|c|c|c|c|}
\hline \multirow{2}{*}{$\begin{array}{l}\text { Hours } \\
\text { after } \\
\text { injection }\end{array}$} & \multicolumn{2}{|c|}{$\begin{array}{c}\text { Blood } \\
(\% \text { initial value) }\end{array}$} & \multicolumn{2}{|c|}{$\begin{array}{l}\text { Body retention } \\
(\% \text { initial value) }\end{array}$} \\
\hline & $\begin{array}{c}\text { Before } \\
\text { PO4 }\end{array}$ & $\begin{array}{l}\text { After } \\
\text { PO4 }\end{array}$ & $\begin{array}{l}\text { Before } \\
\text { PO4 }_{4}\end{array}$ & $\begin{array}{l}\text { After } \\
\text { PO4 }\end{array}$ \\
\hline 2 & $72.0 \pm 3.7$ & $68.6 \pm 3.4 \ddagger$ & 一 & - \\
\hline 4 & $55.2 \pm 5.4$ & $50.3 \pm 4.4 \ddagger$ & - & - \\
\hline 24 & $24.0 \pm 4.2$ & $21.8 \pm 3.5$ & - & - \\
\hline 48 & $14.0 \pm 3.0$ & $10.4 \pm 2.3 \S$ & - & - \\
\hline 72 & $8.4 \pm 2.1$ & $5.9 \pm 2.4 \ddagger$ & $79.5 \pm 0.7$ & $83.1 \pm 5.1$ \\
\hline 96 & $5.6 \pm 1.4$ & $4.0 \pm 1.7 \S$ & $72.1 \pm 4.2$ & $80.4 \pm 4.5 \|$ \\
\hline
\end{tabular}

* Shown as means \pm SD.

$\ddagger$ For difference from initial value, $P<0.05$.

$\$$ For difference from initial value, $P<0.01$.

$\|$ For difference from initial value, $P<0.001$.

10 months (20). Urinary calcium (10) and phosphate were measured at 1 and 10 months. Serum was obtained at 5 and 10 months for PTH immunoassay (15). Serum was obtained at 8 months for measurement of blood urea nitrogen (14). 5 days before the dogs were killed, the ${ }^{47} \mathrm{Ca}$ studies were repeated.

The dogs were given tetracycline orally $(20 \mathrm{mg} / \mathrm{kg})$ every other day, four times, and then were killed $40 \mathrm{hr}$ after the last tetracycline dose. Alizarin red was injected to identify the last label of tetracycline. Immediately before the dogs were killed, an ophthalmologic examination was performed to evaluate the development of cataracts. At autopsy all the viscera were examined closely. Specimens from heart, kidney, thoracic and abdominal aorta, gluteus muscle, and hamstring tendon were saved for estimation of calcium content. The tissue samples were dried, acetone extracted to remove fat, ground, weighed, and dissolved in $3 \mathrm{ml}$ of concentrated $\mathrm{HCl}$. The solution was diluted with $3 \mathrm{ml}$ of distilled water and the calcium concentration was measured with an atomic absorption spectrophotometer (10). Samples of these same tissues were also taken and fixed in neutral formalin for histologic examination by von Kossa's stain.

Bone mineral content and bone diameter were measured at the end of 5 and 10 months of the experimental period; in two animals the bone diameter measurement exceeded the pretreatment value by $15 \%$, indicating that the original

TABLE III

Bone Formation and Resorption in Phosphate-Fed Dogs*

\begin{tabular}{|c|c|c|c|}
\hline Measurement & Sample & $\begin{array}{c}\text { Ulna } \\
\text { (cortical bone) }\end{array}$ & $\begin{array}{c}\text { Iliac crest } \\
\text { (cortical and } \\
\text { trabecular bone) }\end{array}$ \\
\hline $\begin{array}{l}\text { Resorption } \\
\text { (\% total surface) }\end{array}$ & $\begin{array}{l}\text { Before PO، } \\
\text { After PO }\end{array}$ & $\begin{array}{l}3.4 \pm 1.6 \\
7.2 \pm 3.3 \ddagger\end{array}$ & $\begin{array}{c}2.7 \pm 1.4 \\
16.7 \pm 3.5 \ddagger\end{array}$ \\
\hline $\begin{array}{l}\text { Formation } \\
\text { (\% total surface) }\end{array}$ & $\begin{array}{l}\text { Before PO4 } \\
\text { After } \mathrm{PO}_{4}\end{array}$ & $\begin{array}{l}4.0 \pm 1.0 \\
1.6 \pm 1.18\end{array}$ & $\begin{array}{l}1.8 \pm 1.6 \\
1.4 \pm 1.0\end{array}$ \\
\hline $\begin{array}{l}\text { Formation rate } \\
(\mu / \text { day })\end{array}$ & $\begin{array}{l}\text { Before } \mathrm{PO}_{4} \\
\text { After PO4 }\end{array}$ & $\begin{array}{l}1.37 \pm 0.44 \\
1.27 \pm 0.52\end{array}$ & \\
\hline $\begin{array}{l}\text { Porosity } \\
\quad \text { (holes/section) }\end{array}$ & $\begin{array}{l}\text { Before PO، } \\
\text { After PO، }\end{array}$ & $\begin{aligned} 70 & \pm 15 \\
150 & \pm 30\end{aligned}$ & \\
\hline
\end{tabular}

* Shown as means \pm SD.

$\ddagger$ For difference from pretreatment value, $P<0.005$.

For difference from pretreatment value, $P<0.05$. scan site had not been reproduced and the values for these animals were not included in the results. Bone samples from the left ulna midshaft and the left iliac crest were processed for microradiographic and porosity measurements as for the control material. Bone formation rates were measured microscopically at a magnification of $\times 1000$ with illumination of mineralized bone sections by ultraviolet light. The distance between tetracycline bands was measured and divided by the number of days between the two labels. The results were expressed in microns per day and represent a measure of the synthetic activity per osteoblast.

\section{RESULTS}

After $6 \mathrm{wk}$ on the control diet the dogs lost an average of $0.7 \mathrm{~kg}$ (mean weight $\pm \mathrm{SD}, 12.4 \pm 1.6 \mathrm{~kg}$ ). After 10 months on the phosphate supplement, all dogs showed further weight loss averaging $0.7 \mathrm{~kg}$ (mean weight $\pm \mathrm{SD}$, $11.7 \pm 1.8 \mathrm{~kg} ; P<0.05)$. The three dogs continued on the control diet for 6 months lost an average of $1.7 \mathrm{~kg}$. We assumed that we were not feeding the animals the amount of food necessary to maintain body weight.

The serum calcium levels in the phosphate-supplemented group did not show any significant change from control values during 9 months of phosphate supplementation; they generally remained within $1 \%$ of the control values (Table I). The serum magnesium also did not change. The serum phosphate decreased and was significantly below pretreatment values most of the time. There was no significant change in the blood urea nitrogen (mean $\pm \mathrm{SD}: 34.1 \pm 9.0 \mathrm{mg} / 100 \mathrm{ml}$ at $0 \mathrm{wk} ; 34.4 \pm$ $5.3 \mathrm{mg} / 100 \mathrm{ml}$ at $32 \mathrm{wk}$ ). The urinary calcium excretion decreased by $40-60 \%$ and the urinary phosphate excretion increased by a factor of 2 to 3 (Table I).

${ }^{47} \mathrm{Ca}$ disappeared from the blood faster after treatment than before treatment (Table II). The total body retention at $96 \mathrm{hr}$ after injection was higher when compared with control values.

The bone turnover, as measured by quantitative microradiography, was significantly changed. In the ulna, the amount of bone formation decreased by a factor of 2.5 while bone resorption doubled; in the iliac crest, bone resorption was markedly increased (Table III). Bone formation rates (from tetracycline labeling) were unaltered by phosphate supplementation. Microscopically, the bone was more porous, with twice as many holes per cross-section at the end of the phosphate-supplement period (Fig. 1). The bone mineral content measurements at 5 months showed no significant change from the control values in the group as a whole, although in two animals, the values for bone mineral content and bone mineral content divided by diameter (BM/BD) had decreased. At 10 months, bone mineral content and $\mathrm{BM} / \mathrm{BD}$ showed a mean ( $\pm \mathrm{SD})$ loss of bone of $6.9 \pm 3 \%(P<0.005)$; this was found to be significant despite the variation in the control values. There was no significant change in bone diameter (Table IV). The loss of bone mass was 

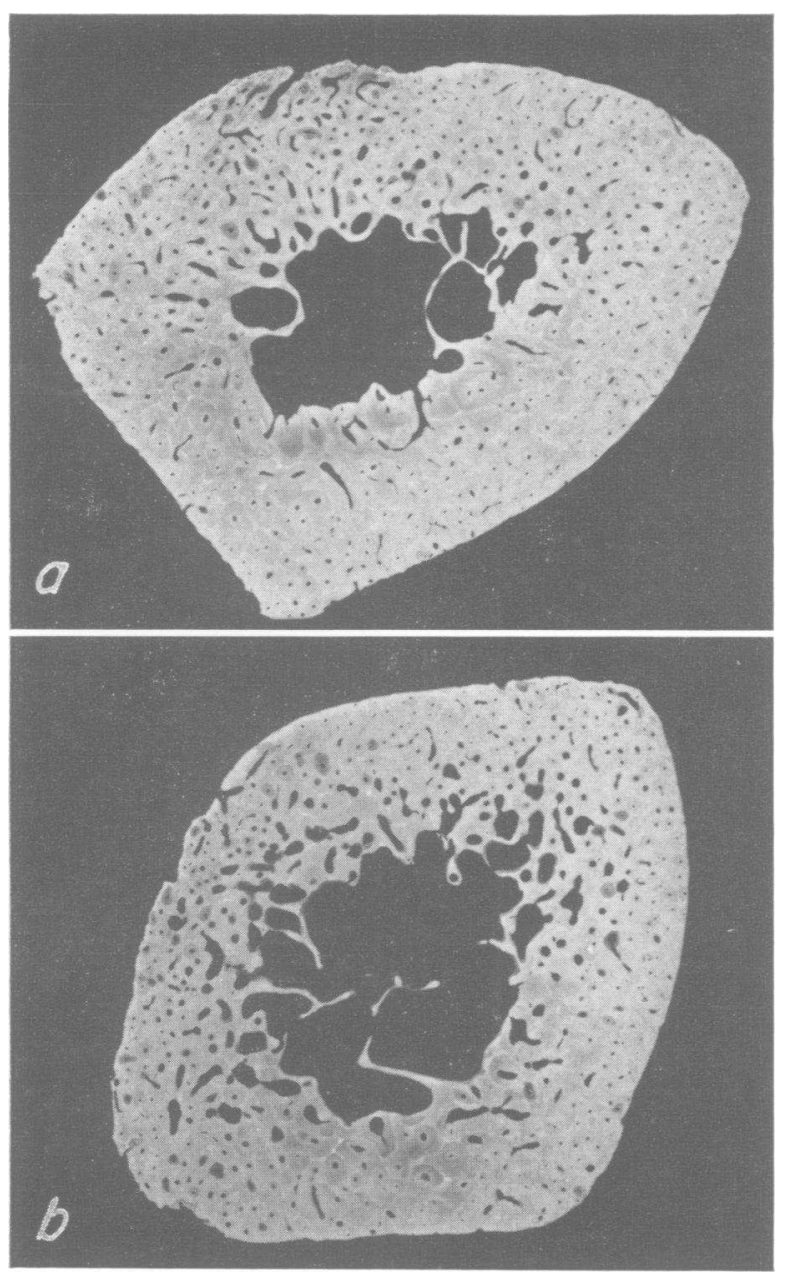

Figure 1 Microradiographs of cross-sections through midshaft of ulna of dog. $a$, before treatment; $b$, after 10 months of phosphate supplementation there is increased porosity of bone.

significantly correlated with the increase in bone resorption and in porosity in the ulna (Table V).

The serum immunoreactive PTH levels were within the normal range in all but one dog during the control period: they increased as a result of phosphate supplementation $(P<0.005)$ in all but one $\operatorname{dog}$ (Fig. 2$)$. PTH changes correlated positively with the decrease in bone mineral content and with the change in bone resorption in the iliac crest and negatively with the serum phosphate (Table V). Bone resorption also correlated negatively with serum phosphate levels.

After treatment, scattered calcium deposits were found in the lenses of 8 of 10 dogs: in 5 of the 8 the calcium deposits were associated with changes compatible with cataracts. The calcium content was increased significantly in the tendon, thoracic aorta. kidneys, and heart as compared with tissues of 10 normal dogs (Table VI). Histo-
TABLE IV

Densitometry Measurements in Eight Dogs

\begin{tabular}{|c|c|c|c|c|c|c|}
\hline \multirow[b]{2}{*}{ Dog } & \multicolumn{4}{|c|}{ Control period } & \multirow[b]{2}{*}{5 month } & \multirow[b]{2}{*}{10 month } \\
\hline & \multicolumn{3}{|c|}{ Individual values } & Mean & & \\
\hline \multicolumn{7}{|c|}{ Bone mineral content, $\mathrm{g} / \mathrm{cm}$} \\
\hline 1 & 0.99 & 0.99 & 0.99 & 0.99 & 0.89 & 0.87 \\
\hline 2 & 1.08 & 1.10 & 1.06 & 1.08 & 1.06 & 0.94 \\
\hline 3 & 0.9 .3 & 0.97 & 0.97 & 0.96 & 0.96 & 0.92 \\
\hline 4 & 0.85 & 0.77 & 0.86 & 0.83 & 0.83 & 0.84 \\
\hline 5 & 0.78 & 0.81 & 0.83 & 0.81 & 0.80 & 0.77 \\
\hline 6 & 0.86 & 0.85 & 0.87 & 0.86 & 0.85 & 0.81 \\
\hline 7 & 0.89 & 0.85 & 0.84 & 0.86 & 0.78 & 0.73 \\
\hline 8 & 0.65 & 0.66 & 0.72 & 0.68 & 0.69 & 0.65 \\
\hline \multicolumn{7}{|c|}{ Bone diameter, $\mathrm{cm}$} \\
\hline 1 & 1.31 & 1.34 & 1.31 & 1.32 & 1.30 & 1.29 \\
\hline 2 & 1.30 & 1.34 & 1.29 & 1.31 & 1.30 & 1.33 \\
\hline 3 & 1.23 & 1.25 & 1.22 & 1.23 & 1.22 & 1.21 \\
\hline 4 & 1.19 & 1.08 & 1.14 & 1.14 & 1.17 & 1.12 \\
\hline 5 & 1.2 .3 & 1.22 & 1.18 & 1.21 & 1.18 & 1.16 \\
\hline 6 & 1.08 & 1.11 & 1.08 & 1.09 & 1.09 & 1.13 \\
\hline$i$ & 1.07 & 1.10 & 1.02 & 1.06 & 0.99 & 1.02 \\
\hline 8 & 1.01 & 1.01 & 1.01 & 1.01 & 1.04 & 1.02 \\
\hline \multicolumn{7}{|c|}{ Bone mineral content/bone diameter, $\mathrm{g} / \mathrm{cm}$} \\
\hline 1 & 0.76 & 0.74 & 0.76 & 0.75 & 0.62 & 0.68 \\
\hline 2 & 0.8 .3 & 0.82 & 0.82 & 0.82 & 0.82 & 0.71 \\
\hline 3 & 0.76 & 0.78 & 0.80 & 0.78 & 0.79 & 0.7 .5 \\
\hline 4 & 0.72 & 0.71 & 0.75 & 0.73 & 0.71 & 0.75 \\
\hline 5 & 0.63 & 0.67 & 0.71 & 0.67 & 0.68 & 0.67 \\
\hline 6 & 0.80 & 0.77 & 0.80 & 0.79 & 0.78 & 0.72 \\
\hline 7 & 0.83 & 0.78 & 0.82 & 0.81 & 0.79 & 0.72 \\
\hline 8 & 0.64 & 0.65 & 0.71 & 0.67 & 0.68 & 0.64 \\
\hline
\end{tabular}

logic evidence of calcification of soft tissue was confined mainly to the kidneys where all dogs showed multiple microscopic areas of calcification most abundant in the medulla. Three patterns could be differentiated, although all three could be found in the same specimen. Most common was the appearance of an intratubular obstructing

TABLE V

Correlations between Measurements in Phosphate-Fed Dogs

\begin{tabular}{|c|c|c|c|c|}
\hline \multicolumn{2}{|c|}{ Correlates* } & \multirow[b]{2}{*}{$\mathrm{N}$} & \multirow[b]{2}{*}{$r$} & \multirow[b]{2}{*}{$P$} \\
\hline $\mathrm{A}$ & $\mathrm{B}$ & & & \\
\hline Serum PO, & $\mathrm{R} \%$ ulna & 20 & -0.57 & $<0.01$ \\
\hline Serum PO، & $\mathbf{R} \%$ iliac crest & 20 & -0.72 & $<0.001$ \\
\hline Serum PO4 & Serum PTH & 20 & -0.44 & $<0.05$ \\
\hline $\mathbf{R} \%$ iliac crest & Serum PTH & 20 & 0.70 & $<0.001$ \\
\hline$\Delta$ Bone mass & $\Delta$ Serum PTH & 10 & 0.66 & $<0.05$ \\
\hline$\Delta$ Resorption, ulna & $\%$ Loss in bone mass & 10 & 0.78 & $<0.01$ \\
\hline$\Delta$ Porosity, ulna & $\Delta$ Bone mass & 10 & 0.87 & $<0.001$ \\
\hline$\Delta$ Resorption, ulna & $\Delta$ Porosity, ulna & 10 & 0.52 & NS \\
\hline $\begin{array}{l}\text { Porosity before PO } \\
70 \pm 15\end{array}$ & $\begin{array}{l}\text { Analysis of compared } \\
\text { Porosity after PO } \\
150 \pm 30\end{array}$ & 10 & & $<0.001$ \\
\hline $\begin{array}{l}\text { PTH before } \mathrm{PO}_{4} \\
56 \pm 11\end{array}$ & $\begin{array}{l}\mathrm{PTH}_{120 \pm 32} \text { after } \mathrm{PO}_{4} \\
\end{array}$ & 10 & & $<0.001$ \\
\hline $\begin{array}{l}\text { Bone mass before } \mathrm{PO}_{4} \\
0.88 \pm 0.11\end{array}$ & $\begin{array}{l}\text { Bone mass after } \mathrm{PO}_{4} \\
0.82 \pm 0.09\end{array}$ & 10 & & $<0.005$ \\
\hline
\end{tabular}

$* \mathrm{R} \%=$ per cent resorbing surfaces.

$\ddagger$ Values shown as means \pm SD. 


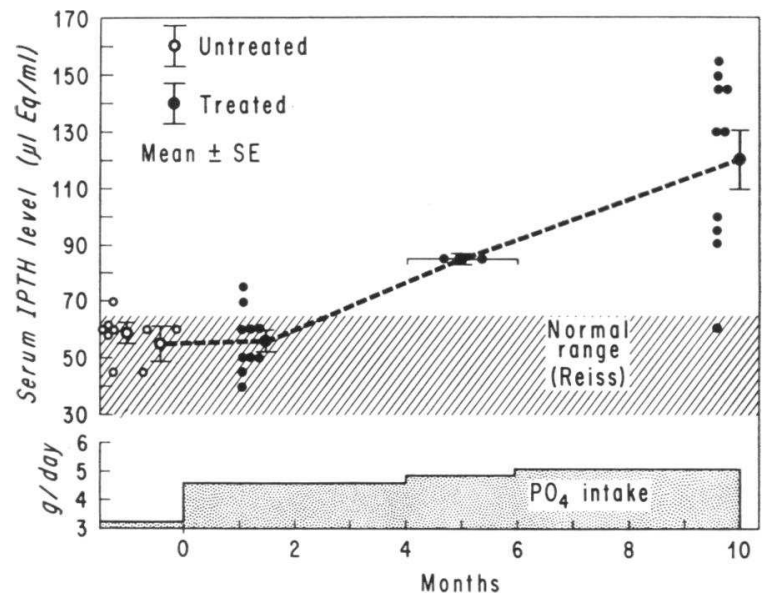

FIGURE 2 Serum immunoreactive parathyroid hormone (IPTH) levels. Untreated dogs are the control group maintained on the nonsupplemented diet; these values are those recorded at 6 months.

cylinder generally found in the medulla (Fig. $3 a$ ); a less frequent finding was a nonuniform tubular deposit composed of medium-sized granules (Fig. $3 b$ ). The third pattern was the presence of fine intracellular crystals. No calcified deposits were found in the glomeruli. In the remaining soft tissues, no calcium deposits were demonstrated histologically and the tissues appeared normal.
TABLE VI

Calcium Content of Soft Tissue*

\begin{tabular}{|c|c|c|c|}
\hline Tissue & $\begin{array}{l}\text { Control } \\
(\mathrm{N}=10)\end{array}$ & $\begin{array}{l}\text { PO4 fed } \\
(N=10)\end{array}$ & $P$ \\
\hline Kidney & $0.408 \pm 0.130$ & $4.04 \pm 1.97$ & $<0.001$ \\
\hline Tendon & $0.239 \pm 0.036$ & $0.279 \pm 0.034$ & $<0.05$ \\
\hline Heart & $0.127 \pm 0.015$ & $0.173 \pm 0.034$ & $<0.005$ \\
\hline Thoracic aorta & $0.365 \pm 0.055$ & $0.469 \pm 0.116$ & $<0.05$ \\
\hline Abdominal aorta & $0.376 \pm 0.106$ & $0.417 \pm 0.077$ & NS \\
\hline Muscle & $0.153 \pm 0.017$ & $0.197 \pm 0.132$ & NS \\
\hline
\end{tabular}

* Means $\pm \mathrm{SD}$, expressed as $\mathrm{mg} / \mathrm{g}$ dry, fat-free tissue.

None of these findings were seen in the animals given the control diet for 6 months.

\section{DISCUSSION}

In adult dogs, oral phosphate supplements appear to result in an increase of bone resorption, which is not accompanied by increased bone formation. The result is a loss of bone tissue, which is reflected both in the bone porosity measurements and in the bone mass values. In man, phosphate supplements failed to alter the progress of bone loss resulting from disuse (21). Although bone atrophy in response to bed rest most probably has a different etiology and mechanism from that of the dietary type studied here, it is relevant that there was apparently
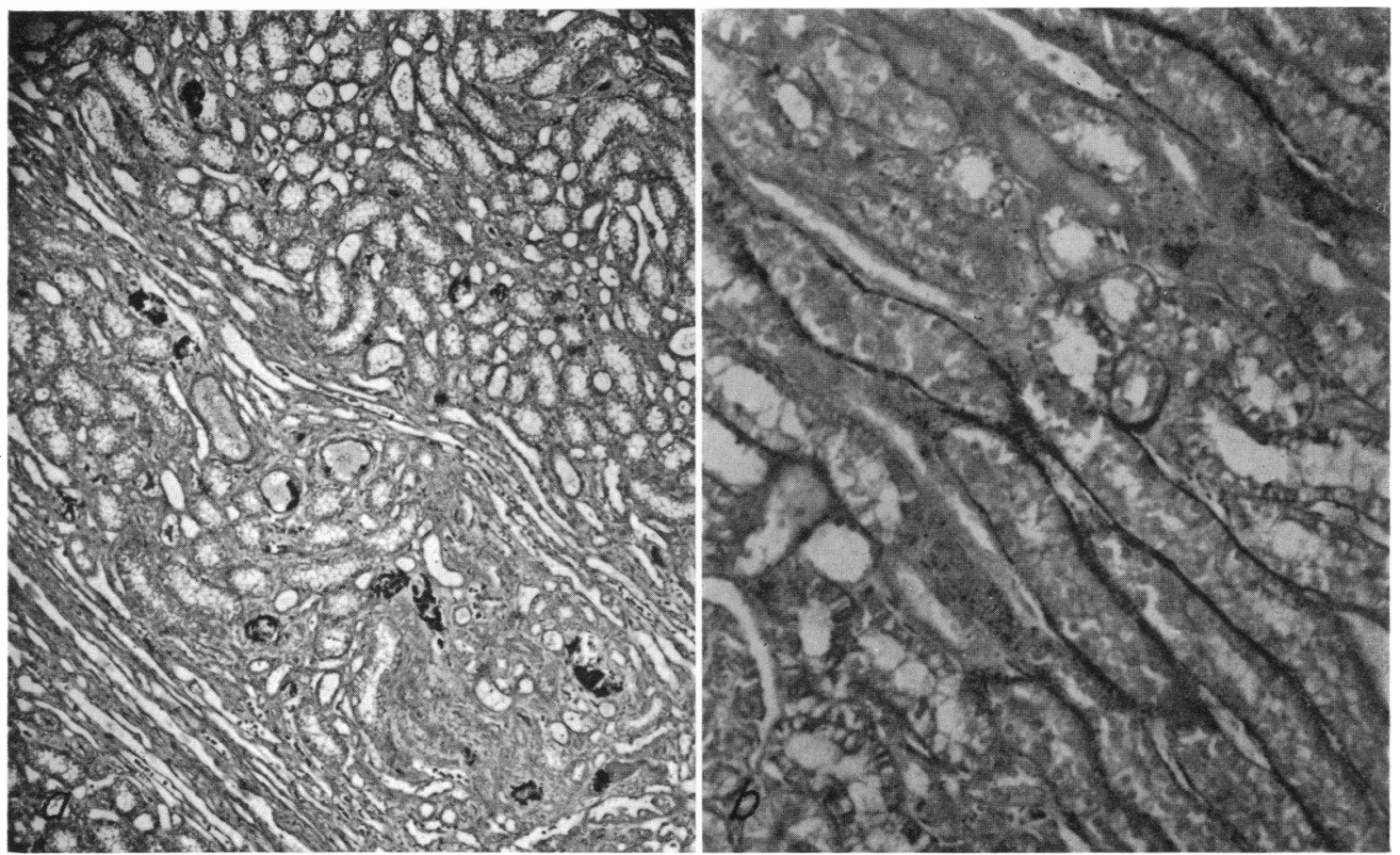

FIgURE 3 Kidney from dog after 10 months of phosphate supplementation. $a$, deposits of calcium in tubules (von Kossa; $\times 65$ ). $b$, fine granular deposit on walls of tubules (von Kossa ; $\times 160)$. 
no response by the skeleton, either as a decrease in resorption or a net increase in formation. In previous studies in dogs, renal insufficiency has resulted in an increase in circulating immunoreactive PTH when the oral phosphate levels were normal; the increase could be prevented by a low phosphate intake (15). In the presence of normal kidney function, a relatively small increase in oral phosphate intake in the present animals resulted in loss of bone mass mediated by increased PTH secretion. It has been suggested (22) that the mechanism is through a transient hyperphosphatemia which induces hypocalcemia which in turn stimulates PTH secretion. The latter would tend to restore the serum calcium levels to normal and depress the serum phosphate. In the present study there was a slight but significant decrease in the fasting (morning) serum phosphate value, which reflected the development of secondary hyperparathyroidism. The negative correlation between these two expressions of increased parathyroid hormone secretion-serum phosphate decrease and bone resorption increase-suggests that, in individual dogs, the higher the PTH level, the greater the influence on both the serum phosphate and stimulation of bone resorption.

The decrease in urinary calcium and the increase in isotope retention reflected total body retention of calcium and confirms previous studies in both animals and man which showed that phosphate supplements result in increased body retention of calcium $(23,24)$. Previously it had been suggested that the skeleton is the site of calcium retention, which had led to the hope that calcium retention reflected a bone mass increase $(2,3)$. However, the present studies show that the calcium is deposited in all tissues and particularly in specific soft tissues such as the kidney. In vitamin D-induced hypercalcemia in rats, phosphate supplementation resulted in calcification of heart muscle and kidney, which proved fatal in some animals (7). Calcification also may occur in the absence of hypercalcemia; previous studies in this laboratory in adult normocalcemic rabbits demonstrated calcification of both kidney and thoracic aorta as a result of oral phosphate supplementation (10). In the adult dogs in the present study, chemical evidence of soft-tissue calcification and histologic evidence of calcification in the lens of the eye and in the kidney is seen in the absence of high serum calcium and phosphate levels in fastingstate samples. It is clear that, while many studies of the treatment of hypercalcemia in man have failed to show calcium deposits in tissues (20), this judgment depends on the absence of gross deposits of mineral evident to the eye. The present investigation strongly suggests that accumulation of calcium occurs throughout the body in the majority of soft tissues and that it need not be preceded by hypercalcemia.
Although the sequestration of mineral in soft tissue is the most serious complication of phosphate supplementation, the effect on bone through parathyroid gland stimulation is possibly a more common medical problem. It is true that the average person ingests approximately $1 \frac{1}{2}-2$ times as much phosphate as calcium in the diet. It has been shown, in short-term studies in man (8) and now in long-term studies in dogs, that phosphate ingestion results in increased PTH levels. Recently, in a group of untreated osteoporotic patients the phosphate intake was related to their bone resorption level (25). In animals, bone loss or osteoporosis resulted from a dietary phosphorus-to-calcium ratio greater than 1 ; only when the intake ratio was close to or less than 1 was bone mass unchanged (10).

Apart from the reflection the present study has on the etiology of osteoporosis, it is probable that phosphate supplementation will aggravate, not reverse, bone-loss disorders, including metabolic bone diseases such as osteoporosis. The dose used in the study was higher than that customarily used in man; however, lower doses over a longer period may have similar effects. The increase in soft-tissue calcium would also contraindicate the use of phosphate in the treatment of hypercalcemia unless this was a life-threatening condition unresponsive to other forms of treatment.

\section{ACKNOWLEDGMENTS}

We very much appreciate the measurements of serum immunoreactive parathyroid hormone which were made by Eric Reiss and Janet Canterbury of the Michael Reese Hospital and Medical Center of Chicago.

This investigation was supported in part by Research Grant AM-8658 from the National Institutes of Health, Public Health Service.

\section{REFERENCES}

1. Goldsmith, R. S. 1970. Multiple effects of phosphate therapy. N. Engl. J. Med. 282: 927.

2. Raisz, L. G. 1965. Bone resorption in tissue culture. Factors influencing the response to parathyroid hormone. J. Clin. Invest. 44: 103.

3. Pechet, M. M., E. Bobadilla, E. L. Carroll, and R. H. Hesse. 1967. Regulation of bone resorption and formation. Influences of thyrocalcitonin, parathyroid hormone, neutral phosphate and vitamin $\mathrm{D}_{3}$. Am. J. Med. 43: 696 .

4. Goldsmith, R. S., C. F. Woodhouse, S. H. Ingbar, and D. Segal. 1967. Effect of phosphate supplements in patients with fractures. Lancet. 1: 687.

5. Goldsmith, R. S., and S. H. Ingbar. 1966. Effects of oral phosphate supplements in demineralizing disorders of bone. J. Clin. Invest. 45 : 1014. (Abstr.)

6. Goldsmith, R. S. 1970. Discussion. (Pharmacology of bone.) Fed. Proc. 29: 1198

7. Spaulding, S. W., and M. Walser. 1970. Treatment of experimental hypercalcemia with oral phosphate. J. Clin. Endocrinol. Metab. 31 : 531.

8. Reiss, E., J. M. Canterbury, M. A. Bercovitz, and E. L. Kaplan. 1970. The role of phosphate in the 
secretion of parathyroid hirmone in man. J. Clin. Invest. 49: 2146 .

9. Anderson, G. H., H. H. Draper, and J. Kastelic. 1970. Enhanced bone resorption in adult rats fed a high phosphate diet. Fed. Proc. 29: 566. (Abstr.)

10. Jowsey, J., and P. Balasubramaniam. 1972. Effect of phosphate supplements on soft-tissue calcification and bone turnover. Clin. Sci. (Oxf.). 42: 289.

11. Slavin, W. 1968. Atomic Absorption Spectroscopy. Interscience Publishers, Inc., New York.

12. Frings, C. S., R. Rahman, and J. D. Jones. 1966. Automated method for the determination of serum inorganic phosphorus. Comparison with manual procedure. Clin. Chim. Acta. 14: 563.

13. Marsh, W. H., B. Fingerhut, and E. Kirsch. 1959. Adaptation of an alkaline phosphatase method for automatic colorimetric analysis. Clin. Chem. 5: 119.

14. Marsh, W. H., B. Fingerhut, and E. Kirsch. 1957. Determination of urea nitrogen with the diacetyl method and an automatic dialyzing apparatus. Am. J. Clin. Pathol. 28: 681.

15. Slatopolsky, E., S. Caglar, J. P. Pennell, D. D. Taggart, J. M. Canterbury, E. Reiss, and N. S. Bricker. 1971. On the pathogenesis of hyperparathyroidism in chronic experimental renal insufficiency in the dog. $J$. Clin. Inc'est. 50: 492.

16. Gomori, G. 1942. A modification of the colorimetric phosphorus determination for use with the photoelectric colorimeter. J. Lab. Clin. Med. 27: 955.

17. Cameron, J. R., R. B. Mazess, and J. A. Sorenson. 1968. Precision and accuracy of bone mineral determination by direct photon absorptiometry. Invest. Radiol. 3: 141.
18. Cameron, J., and J. A. Sorenson. 1970. Measurement of bone mineral by the direct photon absorption method: principles and instrumentation. In Progress in Methods of Bone Mineral Measurement. (Conference sponsored by National Institute of Arthritis and Metabolic Diseases, 1968.) U. S. Department of Health, Education, and Welfare, Bethesda. 253.

19. Jowsey, J. 1966. Quantitative microradiography. A new approach in the evaluation of metabolic bone disease. Am. J. Med. 40: 485.

20. Goldsmith, R. S., H. Bartos, S. B. Hulley, S. H. Ingbar, and W. C. Moloney. 1968. Phosphate supplementation as an adjunct in the therapy of multiple myeloma. Arch. Intern. Med. 122: 128.

21. Hulley, S. B., J. M. Vogel, C. L. Donaldson, J. H. Bayers, R. J. Friedman, and S. N. Rosen. 1971. The effect of supplemental oral phosphate on the bone mineral changes during prolonged bed rest. J. Clin. Invest. 50: 2506.

22. Reiss, E., and J. M. Canterbury. 1971. Genesis of hyperparathyroidism. Am. J. Med. 50: 679.

23. Breuer, R. I., and J. LeBauer. 1967. Caution in the use of phosphates in the treatment of severe hypercalcemia. J. Clin. Endocrinol. Metab. 27: 695.

24. Carey, R. W., G. W. Schmitt, H. H. Kopald, and P. A. Kantrowitz. 1968. Massive extraskeletal calcification during phosphate treatment of hypercalcemia. Arch. Intern. Med. 122: 150.

25. Jowsey, J., B. L. Riggs, P. J. Kelly, and D. L. Hoffman. 1972. Effect of combined therapy with sodium fluoride vitamin $\mathrm{D}$, and calcium in osteoporosis. $\mathrm{Am}$. J. Med. 53: 43. 